\title{
Building Student's Character in Primary School Through Sustainable Development Goals (SDGs) of School Program
}

\author{
Effy Mulyasari ${ }^{1,2}$, Mohammad $\mathrm{Ali}^{2}$, Dadang Sukirman ${ }^{2}$ \\ ${ }^{1}$ Primary Teacher School Education, Faculty of Education, Universitas Pendidikan Indonesia, Indonesia \\ ${ }^{2}$ Curriculum Development Study Program of Post Graduate School, Universitas Pendidikan Indonesia, Indonesia
}

\begin{abstract}
Primary school as a place of learning is expected to be able to provide initial experience to introduce how to create solutions to problems and find new paths to a better and more sustainable future. We as individuals and community members in schools together with the government are responsible for creating a prosperous life. This research is to find out what activities have been carried out in schools that support the Sustainable Development Goals Program (SDGs). From these school activities, what characters can be built? What activities can be added to shaping the character of students in elementary schools? The research method is qualitative, with the type of document and content analysis, and interviews. The data of this study came from 54 primary schools consisting of 27 public and 27 private primary schools, representing 8 provinces in 18 districts/cities with accreditation A $87 \%$, accreditation B 9\%, and other $4 \%$ have not yet released the accreditation. The implementation of school programs referred to 17 SDGs programs. The results obtained by activities carried out by primary schools helped develop programs of Quality Education $55 \%$, Life on Land 33\%, Zero Hunger, and Good Health \& Well Being 6\%. Five main character values can be formed, namely, religion, nationalism, independence, cooperation, and integrity. Other activities that can be added to the school program include; donate items that are no longer used; don't waste food \& support local farmers; avoid wasting water; use energy-efficient tools; bike, walk or use public transportation; bring your shopping bag; turn off lights; take a quick shower.
\end{abstract}

\section{CONTACT}

effy@upi.edu

\section{KEYWORDS}

school program,

sustainable development goals, building students' character

\section{INTRODUCTION}

According to the OECD (Organization for Economic Co-operation and Development) that the goal of the 17 SDGs (Sustainable Development Goals) is to unite countries in the United Nations with a focus on reducing poverty and improving a sustainable quality of life. Education is one of the important goals to achieve, namely improving global competence to help prepare the next generation in dealing with problems that will arise in the future [1,5]. The Government of Indonesia developed the Curriculum 2013 which also supports the achievement of good quality education in line with the objectives of SDGs number four who expect the achievement of 'quality education.'

Education is considered the best place to prepare the agent of change to bring prosperity to the nation. School is not only a place to transfer knowledge but also as a place to build students' attitudes, behavior, character, and leadership $[15,6]$. Therefore, school programs had to develop their program in the correlation between cocurricular, extra-curricular \& intra-curricular programs. It is to build a strong generation in 2045, and it starts now.

Elementary school programs in Indonesia implement Curriculum 2013, by directing to scientific approach learning, but not all schools can implement it optimally. Extracurricular activities are activities conducted by the school to complement and enrich the student experience. Schools everywhere are expected to be following the current curriculum guidelines, namely curriculum 2013, or famously called K13. All schools are trying to make real equality in Education the fourth goal.

School as a co-curricular organizer, in cooperation with the community \& home environment as an influential environment in the formation of one's character or personality. Home as an intra-curricular environment that needs to synergize with schools and communities. All activities are directed to optimize the students' development both low and high grades. Suharta, Septiati, and Kusumawardani (2020) found that character building can be done by accelerating school \& family partnership in a more informal learning context [11].

There are seventeen Sustainable Development Goals (SDGs) planned by UNESCO to save the earth, through balancing all aspects related to human existence and all human survival needs. There are 17 goals to be achieved in 2030 in developing this SDGs program, namely: 1) No Poverty, 2) Zero Hunger, 3) Good Health \& Well Being, 4) Quality Education, 5) Gender Equality, 6) Clean Water \& Sanitation, 7) Affordable \&Clean Energy, 8) Decent 
Work \& Economic Growth, 9) Industry, Innovation \& Infrastructure, 10) Reduced Inequalities, 11) Sustainable Cities \& Communities, 12) Responsible Consumption \& Production, 13) Climate Action, 14) Life Below Water, 15) Life on Land, 16) Peace, Justice \& Strong Institutions, and 17) Partnership for the Goals [3, 4]. All these programs balance the state of the earth as well as human beings as its inhabitants so that they can coexist and strengthen each other in all corners of the world. It is expected that there is no dumping as the disposal of unnecessary goods or garbage to other countries or other places to clean up in its place but endanger other places. So that all programs developed, socialized to the wider community can be through schools or other programs to help keep the earth into a healthy ecosystem.

This research is initial research to find out what activities have been offered/implemented by the school in support of SDGs (Sustainable Education Goals) and of course help the formation of student character, which is also part of the National Education program. From the survey data obtained, it is argued that not all SDGs programs are introduced to students, so there are still few topics offered in elementary school activities. Then it is necessary to find out what programs have been offered by the school or teachers in introducing students to the SDGs program as part of our responsibility on the part of each family, school, and community.

Not many parents, schools' communities are familiar with the program launched by the United Nations in maintaining the continuity of the earth. This is important because it is a shared responsibility. After all, we all live on this beautiful earth. There has been no other search that mentions there is a planet as good as earth. Therefore, we need to maintain the survival of this earth, to be habitable decently by the next generation.

By knowing the public's understanding of this SDGs program, it is expected that together with the government and schools can introduce more programs that can be directly applied in daily life so that it can be done by every community. Although the impact cannot be directly felt, the hope will be seen the results of implementation or implementation of a sustainable or continuous will reduce the adverse global impacts, such as global warming, and reduced oxygen by doing greening or planting trees massively also take care of it until it can contribute to the earth. In addition to providing oxygen, maintaining groundwater, and maintaining the earth's environment.

It is not yet known the extracurricular activities offered in elementary schools that certainly support the quality of educational programs as the $4^{\text {th }}$ objective and must continue to be supported to achieve a good quality of education in all regions of the archipelago. This is necessary so that the development of the extra-curricular program can improve \& support the co-curricular program or the main program of the school.

This research is to find out what activities have been carried out in schools that support the Sustainable Development Goals Program (SDGs). From these school activities, what characters can be built? What activities can be added to shaping the character of students in elementary schools?

\section{METHODS}

The research method is qualitative, with the type of document and content analysis, and interviews. Content analysis is one of the solutions of research tasks in solving a research problem [14]. The initial data of the survey was obtained through online documents spread across 54 elementary schools represented by $74 \%$ in West Java, $6 \%$ in DKI Jakarta, 4\% East Java, 4\% DIY, 4\% in West Sumatra, and the rest in Lampung, Jambi, South Sulawesi, Riau. The elementary school represents 27 public elementary schools and 27 private elementary schools whose accreditation is $87 \%$ already A, $9 \%$ already B, and $4 \%$ have not been accredited. Looking at the accreditation of the school achieved means that the school selected as a sample has achieved a good standard that can optimize the achievement of students both in terms of cognitive, affective \& psychomotor. As we already know that the accretion shows the performance of the school. Setiyaningsih [7] supported in her research conducted in elementary schools that there is a relationship between the accreditation status of the school and the quality of the school.

Furthermore, interviews were conducted at 10 public elementary schools and 10 private elementary schools. as Holloway \&Wheeler in Rachmawati point out, [2] that qualitative research generally uses unstructured or semistructured interviews. In this study, the interview used semi-structured, to obtain more descriptions related to data acquisition at the beginning.

Therefore, this research is expected to provide input for extra-curricular activities in elementary schools. This research is also expected to provide a choice of activities that also improve the quality of education, through school programs.

\section{RESULTS AND DISCUSSIONS}

table: 
Table 1. School Accreditation

\begin{tabular}{llcccc}
\hline No & $\begin{array}{l}\text { Primary } \\
\text { School }\end{array}$ & $\begin{array}{l}\text { Number of } \\
\text { Schools }\end{array}$ & $\begin{array}{l}\text { Accreditation } \\
\text { Grade A }\end{array}$ & $\begin{array}{l}\text { Accreditation } \\
\text { Grade B }\end{array}$ & $\begin{array}{l}\text { Not yet got } \\
\text { Accreditation Grade }\end{array}$ \\
\hline 1 & Public & 27 & 22 & 5 & 2 \\
2 & Private & 27 & 25 & 5 & 2 \\
\cline { 2 - 6 } & & 54 & 47 & $9 \% \%$ & $4 \%$ \\
\hline
\end{tabular}

It showed that the school accreditation would reflect the school's performance. The school will also get quality recognition which is an evaluation in the implementation of the school. With the results of accreditation, the school continues to maintain /improve the quality of teachers \& staff as human resources, infrastructure facilities, school programs, school management, school finance, student outcomes, and school evaluation. So hopefully with good school quality, it will produce good graduates \& quality anyway. It is also a form of responsibility from the school to the community [8]. This accreditation is under the Guidelines of the National Accreditation Board / Madrasah 2020 and also under Government Regulation No. 19 of 2005 on National Standards of Education.

The spread of school territory can be seen below:

Table 2 School Territory

\begin{tabular}{llllll}
\hline No & Province & Public Primary School & Private Primary School & Total & $\mathbf{\%}$ \\
\hline 1 & Jabar & 22 & 18 & 40 & $74 \%$ \\
2 & DKI & 1 & 2 & 3 & $6 \%$ \\
3 & DIY & 1 & 1 & 2 & $4 \%$ \\
4 & Sumbar & 1 & 1 & 2 & $4 \%$ \\
5 & Lampung & 1 & & 1 & $2 \%$ \\
6 & Jambi & 1 & 2 & 1 & $2 \%$ \\
7 & Jatim & & 1 & 2 & $4 \%$ \\
8 & Riau & & 1 & 1 & $2 \%$ \\
9 & Sulsel & & 1 & 1 & $2 \%$ \\
10 & Jateng & & 27 & 1 & $2 \%$ \\
\cline { 2 - 6 } & & 27 & & 54 & \\
\hline
\end{tabular}

The implementation of school programs referred to 17 SDGs programs. The results obtained by activities carried out by primary schools helped develop programs of Quality Education 55\%, Life on Land 33\%, Zero Hunger, and Good Health \& Well Being $6 \%$. The character will be built through the process of habituation, moral knowing, moral feeling, and moral action as discussed by Hidayatulloh in Utami, Soegito, and Muhdi [10].

The extra-curricular program that supported the quality of education referred to refers to spiritual improvement through BTQ activities (Read Write Quran), young hafidz, Sirah nabawiyah, murotal, filling charity boxes on Fridays, memorization Juz 30, santri day. Improvement of social programs and environmental care programs for the sustainability of life on the mainland or your surrounding is by caring for disasters, caring for school environment plants, 'Kang pisman program', utilization of used goods for hydroponics, bringing your drinking bottles, 'babakan resik', green school movement, clean Friday, cross-country activities, SAPO-SAPO (one tree from a student, one tree from a teacher), and 'Adiwiyata school'.

In supporting the quality of education, students also appreciate the local culture by maintaining it through Pencak silat program as traditional self-defense, traditional dance; Jaipong, Peacock dance, Joged Buroq; make Sundanese language Vlog, maintain regional/traditional music such as angklung, degung, calung, karawitan, sing regional songs, marawis, do traditional games, use of Cirebon language, and do 'rebo nyunda.' A new culture that needs to develop is literacy culture. It is not a new culture but we need to build the culture to have a good habit of feeding our mind to improve to the next level [13]. By building literacy culture through reading literacy, writing literacy, financial literacy, technology literacy, and so forth.

In the 1945 Constitution of the State of Indonesia, Article 32, (1) "The state advances Indonesia's national culture in world civilization by guaranteeing the freedom of the people in maintaining and developing their cultural values.". So that the state is responsible for maintaining and advancing the national culture, both the process and its products, as knowledge and skills as a basis for educating students. Kartadinata suggested that ethnopedagogic education as an effort to advance national education based on regional culture will be a collective force of national culture that can be inherited $[16,18]$.

Related to language preservation in the 1945 Constitution of the State of Indonesia, Article 32 (2) "The State respects and maintains the language of the region as a national cultural treasure". Contained the responsibility of the State, through the National Education System, to ensure the sustainability of regional languages as a cultural 
value of sustainable living cultural values in the community, which strengthens national culture and supports the achievement of the whole goal of national education. Therefore, the sustainability of the growth of regional languages is guaranteed by the state. Therefore, as the next generation, students need to be equipped to continue to love, develop \& use their respective regional languages as the nation's cultural wealth $[16,18]$.

Supporting programs without hunger, namely lunch together, eating bajamba, eating fruit every day. This program also supports behaviors or habits including ngarujak culture. Health improvement program with the implementation of toothbrush program, cleaning the environment, putting garbage in place, washing hands, and checking nails.

In improving the character of religion in daily activities, it is carried out praying before learning, habituation of dhuba prayers, performing prayers $d$ zubur congregation. To increase student nationalism, the ceremony is held on Mondays Flag Morning, and big day ceremonies, and visit the museum. In addition to singing national songs, some recite the values of Pancasila. As for extracurricular activities, there are activities to watch together with the film G30SPKI, commemorating the Independence Day of the Republic of Indonesia.

Nowadays, we cannot reject any foreign cultural influences in this era of globalization. Therefore, our sense of nationalism needs to continue to be nurtured \& steadily raised. In addition to the Indonesian nation that has the characteristics of gotong royong or do a collaboration, bersilaturahmi, friendly, it must love and preserve the culture of the Indonesian nation. The culture of manners owned by the Indonesian nation, should not be colonized by other nations. Affan and Maksum (2016) provide some inputs on how to increase our nationalism \& counteract foreign culture, where the government and its people should be able to choose Indonesian culture with 1) Loving domestic products \& culture, 2) Instilling \& practicing Pancasila, 3) Understanding \& implementing it's religious 4) Selectively to foreign cultural influences, 5) Strengthening \& maintaining the identity of the nation [18].

In the development of self-reliance programs implemented among them extra-curricular program among others scouts, PKS, PMR, picket classes. For self-reliance program, it is offered a program of Little Doctor, Child Police, Child Journalists, MABIT in school, Leadership Camp, Study tours far from home, outbound, earthquake simulation, entrepreneurship, English Vlog, and traditional games Vlog.

In the implementation of these activities were also conducted collaboration with his/her group friends. Implementing extracurricular programs needed support as well from the facilities that still become obstacles. That was why the extracurricular program development, was suited to the school facilities. Ongoing process a school will well plan a formal or non-formal program in building students character through short, medium, or long school activities, as an independent person [11]. Other collaboration activities were Drum band, cooking, camping. These activities are also supported by Vivente, Llinares \& Sanches [9] that independence activities can improve students' skills and motivation than can build their character.

Improving Creativity Programs were implemented through Robotics programs, learning English, Coaching Lines Up, IT Competition, utilization of 'jelantah oil'-as diesel oil, coloring, drawing, creativity show, etc. The critical thinking development program is conducted through debate and discussion programs. Market day activities help develop honesty, creativity, collaboration. In addition, teamwork and responsibility become one of the values in students' character that can be integrated into other programs as a game supported by Eliasa [12]. Integrity program development can be done through various sports activities such as football, badminton, table tennis, archery, swimming, rock climbing, etc. Sports games and traditional games were able to improve the cooperation and social ability of the member to practice communication and improve emotional management as well.

Five main character values can be formed from the data above, namely, religion, nationalism, independence, cooperation, and integrity. In reducing inequality, poverty, and protecting the environment in $2030[5,9,11,12$, 13], one of the programs is ensuring the availability and management of clean water and proper sanitation. Another program is waste management such as reduce waste production through prevention, reduction, recycling, and reuse, to ensure sustainable production and consumption patterns [1]. The program needs to be supported, by educating students, parents, and communities. Other activities that can be added to the school program include; donate items that are no longer used, don't waste food and support local farmers, avoid wasting water; use energyefficient tools; bike, walk or use public transportation; bring your shopping bag, turn off lights, and take a quick shower [3,4]. Communication skills as one of $21^{\text {st }}$ Century skills will use any language to deliver someone message to another as a process of interaction. Using a language will motivate someone to develop his/her language skills for reading, listening, speaking, and writing skills [17].

\section{CONCLUSIONS}

From the results of the discussion, we obtained that the activities carried out as extracurricular in elementary schools support the activities of SDGs programs following the direction of the UNESCO Program. Many 
activities that have been done in the school including extracurricular activities, activities offered in schools as extracurricular activities, do not represent all SDGs that want to be achieved.

Therefore, the school as an institution for the quality of education is expected to be able to continue to socialize and giving understanding to students, parents, and the community together to maintain the continuity of this earth by doing activities that can be done daily, such as donate items that are no longer used, don't waste food and support local farmers, avoid wasting water; use energy-efficient tools; bike, walk or use public transportation; bring your shopping bag, turn off lights, and take a quick shower.

With the above school programs seen, five main character values can be formed, namely, religion, nationalism, independence, cooperation, and integrity. In addition, the program also helps students develop their competence as citizens of the 21 st Century who have the skills of creativity, critical thinking, collaboration, and communication.

\section{ACKNOWLEGDEMENTS}

I am grateful for the assistance of the BPPDN scholarship fund year 2020/2021 in the framework of completion of the postgraduate doctoral program in the curriculum development study program, Universitas Pendidikan Indonesia.

\section{REFERENCES}

[1] UNESCO. Education for Sustainable Development Goals. Learning Objectives. Paris: The United Nation. 2017.

[2] Nur Rachmawati, I. N. Pengumpulan data dalam penelitian kualitatif: Wawancara. Jurnal Keperawatan Indonesia, Volume 11, No.1, Maret 2007; hal 35-40

[3] https://www.un.org/sustainabledevelopment/sustainable-development-goals/ (Januari 2020)

[4] https://www.un.org/sustainabledevelopment/wp-content/uploads/2018/10/LazyPersonGuide.pdf (access on 18032021)_Guide Activities for SDGs

[5] Vaccari, V. and Gardinier, M.P. 'Toward one world or many? A comparative analysis of OECD and UNESCO global education policy documents'. International Journal of Development Education and Global Learning, 11 (1): 68-86. 2019. DOI https://doi.org/10.18546/IJDEGL.1

[6] Bialik, Maya \& Fadel Charles. Skills for the $21^{\text {st }}$ Century: What Should Students Learn? Boston: Center for Curriculum Redesign. 2015. (www.curriculumredesign.org)

[7] Setiyaningsih, Charisma Dewi. Status Akreditasi dan Kualitas Sekolah di Sekolah Dasar. Manajemen dan Supervisi Pendidikan, Volume 1, Nomor 2 Maret 2017: 138 - 145

[8] BAN Pedoman Akreditasi Sekolah/Madrasah. Jakarta: BAN-S/M: 2020.

[9] F. Ruiz Vicente, A. Zapatera Llinares, and N. Montés Sánchez, "'Sustainable City’: A Steam Project Using Robotics to Bring the City of the Future to Primary Education Students," Sustainability, vol. 12, no. 22, p. 9696, Nov. 2020.

[10] Utami, Rhisty Frida., Soegito, AT., Muhdi. STRATEGI PEMBINAAN KARAKTER SISWA DI SEKOLAH DASAR ISLAM TERPADU BUAH HATI PEMALANG https://scholar.google.co.id/scholar?q=STRATEGI+PEMBINAAN+KARAKTER+SISWA+DI+SE

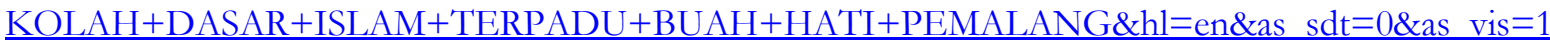
\&oi=scholart

[11] Suharta, Robertus B.; Septiarti, Serafin W.; \& Kusumawardani, Erma. SCHOOL AND FAMILY PARTNERSHIP: INFORMAL LEARNING CONTEXT TO BUILD CHILDREN CHARACTER. Jurnal Ilmiah PTK PNF. http://doi.org/10.21009/JIV.1502.10Volume 15 Number 2 December 2020

[12] Eliasa, Eva Imania. Increasing Values of Teamwork and Responsibility of The Students Through Games: Integrating Education Character in Lectures. Procedia - Social and Behavioral Sciences. 123 (2014) 196 - 203. Available online at www.sciencedirect.com; DOI: 10.1016/j.sbspro.2014.01.1415

[13] Sobirin, Ma'as. \& Susapti, Peni. Universitas Wahid Hasyim Semarang IAIN Salatiga maas.shobirin@unwahas.ac.id. DOI: 10.18326/mudarrisa.v10i2.206-221. Cultural literacy building of primary school students as basic concept. Mudarrisa: Jurnal Kajian Pendidikan Islam, Vol. 10, No. 2, 2018

[14] Fedotova, Olga. \& Platonova, Elena. Contemporary Politics Of Russian Universities In The Development of Human Capital: The New Organizational Platform And Role of The Initiative. Procedia - Social and Behavioral Sciences 141 ( 2014 ) 1177 - 1181. Available online at www.sciencedirect.com

[15] Rokhmana, Fathur., Humb, M., Syaifudin, Ahmad., Yuliati; Character Education For Golden Generation 2045 (National Character Building for Indonesian Golden Years). Procedia - Social and Behavioral Sciences 141 (2014) $1161-1165$ 
[16] Kartadinata, Sunaryo. 2021. Dari Pedagogik ke Pedagogi: Implikasi Imperatif Amanat Konstitusi untuk Bangsa. Bandung: FIP UPI. Februari 2021

[17] Fatimah, \& Sari, Ratna Dewi Kartika: Strategi Belajar \& Pembelajaran dalam Meningkatkan Keterampilan Bahasa Website : https://jurnal.umj.ac.id/index.php/penaliterasi. Pena Literasi, Jumal Pendidikan Bahasa \& Sastra Indonesia. Vol.1, No. 2, Okt 2018

[18] Affan, M. Husin \& Maksum, Hafidh. MEMBANGUN KEMBALI SIKAP NASIONALISME BANGSA INDONESIA DALAM MENANGKAL BUDAYA ASING DI ERA GLOBALISASI. JURNAL PESONA DASAR Universitas Syiah Kuala Vol. 3 No.4, Oktober 2016, hal 65 - 72 ISSN: 2337-9227. 